\title{
Off-farm Labor Supply and Labor Markets in Rapidly Changing Circumstances: Bulgaria during Transition*
}

\author{
Sumon Kumar Bhaumik \\ Aston Business School, Aston University, \\ IZA - Institute for the Study of Labor, Bonn, and \\ William Davidson Institute, University of Michigan, Ann Arbor \\ sumon.bhaumik@gmail.com \\ Ralitza Dimova** \\ Brunel University, and \\ IZA - Institute for the Study of Labor, Bonn \\ Ralitza.Dimova@brunel.ac.uk \\ Jeffrey B. Nugent \\ University of Southern California \\ nugent@almaak.usc.edu
}

\begin{abstract}
:
This study examines off-farm labor supply in the rapidly changing conditions of Bulgaria during the 1990s. In doing so, we make use of three different waves of the Bulgarian Integrated Household Survey, each reflecting remarkably different environmental conditions. The results suggest that standard theories of off-farm labor supply provide little guidance in situations characterized by chronic excess supply in the off-farm labor market and/or rapidly changing circumstances. In particular, the results show (1) that off-farm employment throughout the transition was predominantly demand determined rather than supply determined, and (2) that the magnitude and statistical significance of the various determinants are very sensitive to changing environmental conditions, As such the results can be extremely relevant for both theory and policy for the many countries which may still need to go through privatization and painful restructuring as a result of financial crises and globalization.
\end{abstract}

Key words: off-farm labor supply, entitlement failures, transition economies, Bulgaria JEL classification: J2, P23, P36, O13, Q12

September 5, 2010

\footnotetext{
" The authors would like to thank Joep Konings, Jo Swinnen, Gauthier Lanot and seminar participants at Queen's University Belfast and St. Anthony's College at Oxford University for their comments. They remain responsible for all remaining errors.

Corresponding author. Address: Brunel University, School of Social Sciences, Economics and Finance, Marie Jahoda, Uxbridge UB8 3PH, United Kingdom; Phone: +44 (0)1895 267275; Fax: +44 (0)1895 266649.
} 


\section{Off-farm Labor Supply and Labor Markets in Rapidly Changing Circumstances: Bulgaria during Transition}

\section{Introduction}

The literature on off-farm labor supply - the supply of paid labor by members of farm households for activities outside their own farms - has developed along two quite different lines. ${ }^{1}$ In one of these, the emphasis is on testing whether or not the so-called separation principle, whereby the production and consumption decisions of a farm household are independent of each other, holds. When it does, (a) the demand for labor by farm-owning households is independent of their own labor endowments, and (b) off-farm labor supply by members of these households is independent of the farm characteristics that define the labor input demand for farm activities. There is an extensive literature that tests both these hypotheses (e.g., Huffman, 1980; Benjamin, 1992).

In the other line, almost exclusively applied to poor developing countries, off-farm labor supply is seen as a way to smooth consumption across time (Lanjouw and Lanjouw, 1995). Such studies view off-farm labor supply as an ex post reaction to low farm income, leading to the testable hypothesis that agricultural income and off-farm labor supply would be negatively correlated. ${ }^{2}$

In the latter context, the implicit assumption is that off-farm labor demand serves as a shock absorber for farm families buffeted by changing weather and other supply conditions. The assumption of static demand conditions, however, would appear to be increasingly unrealistic. Indeed, demand can be very volatile due to important policy changes, financial or trade-related shocks and, structural changes such as privatization. In recent years, a most suitable place for observing the effects of rapidly changing demand conditions including privatization is the transition economies of Central and Easter Europe (CEE) which underwent sharp declines subsequent to the abandonment of central planning and the accompanying political changes, but then followed by recoveries of varying intensity but often interrupted by sharp financial and economic crises. However, while a sizeable literature has developed on the nature of the transformation of the manufacturing and public sectors in these countries and its implication for jobs flows and employment, ${ }^{3}$ to date there have been few attempts to use the transition experience to explore alternative views of off-farm labor supply, and indeed none

\footnotetext{
${ }^{1}$ There is a large literature on off-farm labor supply in both developed countries like the USA and Canada (Huffman, 1980; Weersink et al., 1998) and much poorer countries like those of sub-Sahara Africa, Asia and Latin America (e.g., Escobal, 2001; Woldehanna and Oskam, 2001; Oldenhanna and Oskan, 2001; de Janvry and Sadoulet, 2001; Deringer and Olinto, 2001; Lamb, 2003; Joliffe, 2004).

${ }^{2}$ Some researchers also use farm characteristics as proxies for farm income (Ruben and Van den berg, 2001).

${ }^{3}$ See, for example, Bolton et al. (1992), Burda, Bean and Svejnar (1993), Blanchard, Commander and Coricelli (1995), Konings, Lehman and Schaffer (1996), Svejnar (1996, 1999), Walsh and Whelan (2001), Schntzer and Andreyeva (2002), Faggio and Konings (2003), Bezemer (2004), Mickiewicz, Gerry and Bishop (2005), Koford and Miller (2006).
} 
that examine the impact of macroeconomic and structural changes on the nature of the off-farm labor market in these countries.

The transition economies are of interest because, aside from their rapidly changing conditions, they were fundamentally different from both developed and developing economies in two important respects. First, few if any had well functioning labor markets that would be suitable for testing for the separation principle that underpins the off-farm labor supply analysis in developed countries. Second, their farm households were also fundamentally different from those in developing countries in that (1) because of higher levels of education, they were more employable off-farm, and (2) because of the comparative lack of traders, cooperatives and other intermediaries, the ability to sell their farm output was more restricted. ${ }^{4}$

In a transition economy, therefore, one could expect the supply of off-farm labor to be much less affected by farm characteristics or by farm income, even if these were fully measurable. This would be especially so if the marginal productivity of labor on the farms was quite low both absolutely and relative to the marginal productivity of labor in most non-farm activities, as would seem especially likely for the many farm households which had received their land by way of restitution and thus had little relevant experience in farming. ${ }^{5}$ Also, since agriculture was largely a subsistence activity, off-farm non agricultural employment would also have been especially important as a means of earning cash to finance (1) non-food consumption, (2) diversification of the food consumption basket and, (3) capital expenditure (given underdeveloped credit markets after the demise of state owned banks).

In other words, in the transition economy context we hypothesize (1) that off-farm labor supply would be largely (if not entirely) determined by the rapidly changing demand for labor, perhaps complemented by the possession of favorable characteristics such as location and (2) since conditions on the demand side of the labor market, including the characteristics most desired by offfarm employers, were changing rapidly, unlike both developing and developed countries, the influences of worker and household characteristics on off-farm labor supply could be expected to vary quite considerably, even over just a few years.

We examine these demand-driven hypotheses concerning the determinants of off-farm employment by farm households in the context of Bulgaria, which for reasons given below would seem to provide an especially relevant setting for such an examination. Our objective is somewhat

\footnotetext{
${ }^{4}$ It should be recalled how drastic the decline in trade was within the CMEA in the early years of the transition so that along with the decline in government support for cooperatives, the commercial viability of agricultural activity declined precipitously. Nowhere was this decline any more noticeable than in Bulgaria, a country which had been a large agricultural exporter under the CMEA and where there was sudden and massive privatization of state enterprises and restructuring of off-farm activities which made industrial jobs extremely difficult to find. ${ }^{5}$ Restitution was a process begun in Bulgaria in 1992 (The Law of Privatization of State Property) but virtually never observed in developing countries. With restitution and privatization collectivized land was returned (after several decades) to families that had owned the land prior to the collectivisation of agriculture. At the same time, the sudden mass privatization and restructuring of industrial firms made industrial jobs very hard to find.
} 
akin to that of Rizov and Swinnen (2004) for Hungary. In their impressive study Rizov and Swinnen used data from a single survey of farm households to test for the existence of market imperfections in both labor and credit markets, finding evidence for both by examining the influence of various farm and household characteristics on on-farm labor supply. They showed that households with less favourable characteristics and locations worked more on their own farms, presumably because they were rationed out of the off-farm labor market to a greater extent than their better endowed compatriots. This is our perspective as well but we focus on the supply of off-farm labor and more importantly not just in a single period but at several points in time, each characterized by very different conditions in the off-farm sector.

The reasons for choosing Bulgaria for examining the determinants of off-farm labor supply over time are as follows.

First, privatization of land began (via the Land Law of 1991) but was not completed for almost a decade afterwards.

Second, as identified in footnote 4 above, restitution was a relatively important feature which was initiated in 1991 but which was not altogether completed until well after 1995. As documented by Bachev (2008), between 1990 and 2000, some three-fourths of Bulgarian households had come to possess agricultural land and employment in agriculture had risen by 26 percent but for the most part managed by householders with little or no prior experience in agriculture.

Third, even though the agricultural sector remained quite important, accounting for 16 percent of gross material product in the early transition period, agricultural investment had been declining during the socialist era and declined even further during transition due to uncertainty, the precariousness of property rights and the drying up of commercial outlets such as export markets within the former CMEA countries, and difficulty in access to credit.

Fourth, land and labor productivity in agriculture were low and falling as a result of (a) the loss a agricultural capital in the transition because of severe mishandling by the transition agencies such as the privatization board, liquidation councils and land commissions, (b) the breakdown in access to fertilizers, pesticides and especially irrigation, and (c) a decline in the quality of labor due to the exodus of professional managers with privatization (at least until after 2000 when specialized agricultural companies started to be formed).

Fifth, since foreign ownership of land was prohibited during much of the transition period, foreign direct investment in Bulgarian agriculture did not occur.

Sixth, for reasons given above farms were largely subsistence-oriented, a safe source of food for the household, but with much less commercialization than in farms in developed countries or even in many developing countries. ${ }^{6}$

\footnotetext{
${ }^{6}$ Some studies suggested that in the aftermath of the financial crisis of 1996-97 nearly 50 percent of the population (and hence possibly a larger fraction of the rural households) were self-producing half or more of their daily food requirements.
} 
Seventh, despite a reduction in the official size of the labor force on account of adverse demographic changes and deregistration of unemployed people from official records, the off-farm employment situation in the aftermath of the aforementioned crisis was extremely problematic. For example, with the official unemployment rate over 18 percent, the poverty rate rose sharply from 5.5 percent in 1995 to 37 percent in the crisis year 1997. Hence, off-farm labor supply in transition Bulgaria was much more likely to be more strongly affected by considerations of relevance to potential employers such as their education, location and ethnicity than by supply side considerations like relative productivity of labor in farm and non-farm activities and consumption smoothing as in the traditional literature. Due to privatization and the switch from industry to services in off-farm employment, the educational and other characteristics desired by the off-farm sector were changing rapidly. ${ }^{7}$

Last but not least among the advantages of Bulgaria is the ability to make use of data available from the Bulgarian Integrated Household Survey (BIHS) for three points in time, namely, 1995, 1997 and 2001, thereby addressing the one weakness in the Rizov and Swinnen (2004) paper, namely, that it was for a single point in time.

We hypothesize that over the time period 1995-2001, not only was the level of education of household members a key determinant of a farm household's off-farm labor supply, but also, over time, certain types of education may have become less useful and others more useful. In particular, if the labor market is demand constrained, households with a high proportion of university-educated individuals would be more likely to report off-farm jobs than those with a corresponding proportion of members with general non-university education. ${ }^{8}$ It is well documented that in demand-constrained labor markets education is used as a Spence-type screening device, resulting in employer- bias in favor of workers with higher education. This employer bias for higher education, which is generally accompanied by employment of over-educated workers in jobs that have low educational requirements, is observed not just in developing countries but also in developed countries such as Sweden (Aberg, 2003). The benefit of university education is likely to be particularly high in 1997, in the immediate aftermath of the crisis when a large number of jobs were lost on account of the restructuring of the industrial sector. We also hypothesize that, as labor market conditions became more adverse, other factors such as race and ethnicity might become more important, possibly reflecting discriminatory preferences. If these considerations should turn out to be important, some standard policy recommendations, such as the expansion of education of all types, might have to be partially qualified at least in environments characterised by significant excess supply of labor.

\footnotetext{
7 See Dimova and Gang (2005) for evidence.

${ }^{8}$ It is also likely that households with a high proportion of members with vocational education that impart specific skills would be in a better position to supply off-farm labor in a demand constrained market, than households with a high proportion of members with general non-university education. But there is nothing to suggest that this would necessarily be the case.
} 
As will be shown below, our results provide strong support for both the relative unimportance of the traditional determinants of off-farm labor supply (farm productivity and income), and the relative importance of household characteristics considered favourable to potential off-farm employers (like education). Our results also reveal the extent to which the influences of the various factors determining off-farm employment changed over time as environmental conditions changed over the course of the transition.

The rest of the paper is organised as follows: In Section 2, we present our empirical strategy and regression specification for the analysis of off-farm employment. In Section 3, we describe the data, and use it to highlight the trends in some of the characteristics of Bulgaria's farm households during the 1995-2001 period. The regression results are discussed in Section 4. Section 5 concludes.

\section{Empirical Strategy and Specification}

In principle, the determination of the likelihood of off-farm labor participation could be at either the individual or household level. We choose to do so at the household level ${ }^{9}$ for the following reasons: First, since land restitution and the limited number of land rentals in Bulgaria benefited rather disproportionately landowners and tenants in the 50-60 age group (Noev, Swinnen and Vranken, 2004), this would imply that most would also have a spouse and children of working age in the household. Hence, an analysis of the choices of individuals (typically household heads a la Goodwin and Holt (2002)) could be relevant to only a rather limited portion of the age distribution of the Bulgarian population. As indicated in the next section, by focusing on the off-farm labor supply of all working age members of farm households, we obtain a rather balanced sample of working age individuals with mean age of 30-35, thus greatly mitigating the possibility of age-related selection bias. Second, given the large and rapidly changing environmental conditions affecting both on- and off-farm activities, the household level would seem to be the appropriate one for achieving an optimal portfolio of labor allocations. Third, cooperative membership, financial and agricultural assets are observable only at the household level and yet would be more likely to affect the choices of the household as a whole than those of any particular household member. Finally, and perhaps most importantly, since off-farm labor supply is not an end in itself, but rather is of special importance in explaining variations in headcount poverty rates (measured at the household level) over the period under study, we deem it preferable to focus on the ability of the household as a whole to access the off-farm labor market (with its attendant benefits).

In effect, therefore, we assume that each household rationally decides the intra-household distribution of the supply of off-farm labor, and focus on whether or not at least one working age

\footnotetext{
9 Since Kimhi (1980) and Rizov and Swinnen (2004) have also analyzed these decisions at the household level, we are not alone in this respect.
} 
member of a farm household is able to supply labor in the off-farm market. In other words, we estimate the following probit model: ${ }^{10}$

$$
\begin{aligned}
& \mathrm{y}^{*}=\alpha^{\prime} \mathrm{x}+\varepsilon \\
& \mathrm{z}=1, \text { if } \mathrm{y}^{*}>0 \\
& \mathrm{z}=0, \text { if otherwise }
\end{aligned}
$$

where $y$ is the off-farm labor supply of the household, $z$ is the participation in the off-farm labor market by some adult in the household, and $x$ is a vector of explanatory variables.

To recapitulate, in transition Bulgaria, both commercial agriculture and agricultural productivity had suffered severe setbacks after the collapse of both the CMEA and the state-owned banking system, and a significant proportion of the farm owners had obtained access to land by way of restitution. In such a context and in contrast to the literature cited above which focused on the role of farm characteristics, we argue that off-farm labor supply could be expected to be determined largely by factors that influence labor demand. The primary objectives in our empirical analysis are to identify those factors such as education of various types and other personal characteristics that influence the likelihood of off-farm labor supply, and to see how these influences change over time with the rapidly changing environmental conditions including the financial crisis of 1997 . Therefore, we include in the specification vector $x$ both farm characteristics and education, ${ }^{11}$ ethnicity, location and a few other household characteristics as controls.

Specifically, to capture the various farm characteristics that can serve as proxies for farm productivity or farm income as suggested in the traditional literature, we include the size of the farm, a dummy variable for ownership of farm equipment, ${ }^{12}$ and a dummy variable that indicates whether the farm was part of an agricultural cooperative.

For measures of education, we could have used the mean years of education of the working age adults of a household, in a linear, quadratic or quasi-semiparametric functional form. However, given the findings of Dimova and Gang (2004) showing that there was a significant increase in the demand for people with higher education in the post-crisis period, we use instead the proportion of

\footnotetext{
${ }^{10} \mathrm{We}$ also undertake a Tobit analysis in which the dependent variable is the total number of off-farm labor hours supplied by working age household members. The qualitative results are remarkably similar to those of the probit analysis, and hence do not add to our understanding of the phenomenon of off-farm labor supply in Bulgaria during transition. Therefore, we do not report them separately in this paper, but they are available upon request.

${ }^{11}$ The positive impact of education on off-farm labor supply itself is documented in the Bulgarian context (Goodwin and Holt, 2002), but only for one year of the pre-crisis period (i.e., 1995).

${ }_{12}$ Arguably, the value of farm equipment owned by the household would be more informative. However, it is also potentially endogenous; households that supply off-farm labor are also more capable of investing in such equipment. Our experimentation with a wide range of IV regressions suggests that available instruments are weak and hence the IV route to addressing the possible endogeneity problem is infeasible. The cross-section nature of the data also makes it impossible to use alternative approaches such as the generalised method of moments (GMM). Hence, we have opted for a binary indicator of ownership of farm equipment which is much less likely to be affected by off-farm labor supply than the value of such equipment.
} 
working age household members that have different types of education. As argued above, not only should the likelihood of participation in the off-farm labor market and the total supply of off-farm labor be positively related to education, but also higher education should become a more important determinant of this likelihood in the aftermath of industrial restructuring and privatization that followed the financial crisis of 1997.

For other household characteristics that might affect labor demand, we include the following: (1) non-labor (asset) income as suggested by Dasgupta (1993), (2) a dummy for non-Bulgarian ethnicity to capture the influence of discrimination based on ethnicity which would be expected to be stronger when unemployment is especially high, (3) dummy variables for location in an urban area, or in one of the various regions (with the capital Sofia the excluded region), and (4) a series of household-level demographic variables such as the total number of working age adults in the household, the mean age of the working age household members, the proportions of household members who are 0-6, 7-18 and over 60 years of age, and the gender and marital status of the household head (suggested by the findings of Bhaumik, Gang and Yun, 2006).

As in the case of non-Bulgarian ethnicity, one of our main interests in these variables is to see how their influences may have been changing over time. Unfavorable characteristics such as the head being female, location in a rural area, or in a remote province would be expected to have negative influences on the likelihood of off-farm labor supply, and especially so in years of high unemployment. In the case of the proportions of household members who are young - in the 0-6 and 7-18 age categories - or elderly(above 60), however, a priori expectations on the signs of the coefficients associated with these variables are ambiguous. On the one hand, in the face of disappearing low cost (or public) care facilities for children and elderly household members, working age adults may find it increasingly difficult to participate in the off-farm labor market. But on the other hand, such households may require more cash to pay for their education, health care and other expenses, giving them a greater incentive to look for off-farm employment.

\section{Data}

As mentioned earlier in the paper, the three different waves of the BIHS were undertaken in 1995, 1997 and 2001. These three rounds of the BIHS were conducted by Gallup International under the auspices of the Bulgarian Ministry of Labor, the Ministry of Social Affairs and the National Institute of Statistics. The surveys provide detailed information on demographic and family characteristics, employment, income, education and wealth of all household members of about 2500 households. ${ }^{13}$ The sampling procedures used in the surveys ensure that the samples for each of the

\footnotetext{
${ }^{13}$ Specifically, the surveys include information on 2468 households with a total of 7199 members in 1995,2323 households with 6947 members in 1997 and 2633 households with 7844 members in 2001.
} 
surveys are representative. ${ }^{14}$ Given our focus on off-farm labor supply of farm households, our sample consists of those individuals in the approximately 600 households that have access to cultivable land used for farm production. ${ }^{15}$ For labor supply decisions we include only those households with individuals of working age, 18-55 for women and 18-60 for men. ${ }^{16}$

All the variables used in the analysis are listed and defined in Table 1. Table 1 also reports the descriptive statistics on all variables separately for each of the three rounds of the survey and for those households that do and do not supply any off-farm labor. It can easily be seen that the proportion of farm-households supplying off-farm labor declined from 67 percent in 1995 to 61 percent in 1997, in the immediate aftermath of the financial crisis, and remained at that level in 2001.

The descriptive statistics highlight the following: First, while during the "normal" years of 1995 and 2001, farm households that did not supply off-farm labor owned much larger plots of land than those households that reported supplying off-farm labor, the opposite was true in the crisis year 1997 which would be most strongly characterized by demand determination of off-farm labor supply. This is consistent with the possibility that smaller farms are more likely to be owned by subsistence farmers, who are more likely to supply off-farm labor. We revisit this issue later in the paper. Second, all three types of education seem to be positively related to the likelihood of off-farm labor supply. Notably, however, as privatization became common in the aftermath of the financial crisis of 1997, the benefit of general secondary education seemed to decline and indeed disappear by 2001. Finally, households supplying off-farm labor were, on average, more likely to be located in urban areas, and more likely to have asset (or non-labor) income, both of which facilitate off-farm employment in a demand constrained labor market.

Among the other factors that seem positively correlated with the likelihood of off-farm employment are the number of household members of working age (very unsurprisingly), the proportion of household heads who are married, and the proportions of household members which are young (both 0-6 and 7-18), though in this case the difference virtually disappeared by 2001 . On the other hand, off-farm employment is less common in households with higher proportions of household members who are elderly, or from an ethnic minority (i.e., non Bulgarian ethnicity). Note that the

\footnotetext{
${ }^{14}$ The sampling was done in two stages. In the first stage the survey sample was selected. The listing was organized in the following order: (i) the list of 28 regions, (ii) cities and villages within these regions, (iii) each city and village listed by size. In the second stage the interviewed households were selected with equal probability, provided that they have also been listed by size. One of the objectives of the interviewers was to reduce the number of refusals to fewer than $5 \%$. Each refusal and each substitution had to be verified by a team supervisor.

${ }^{15}$ This procedure is in keeping with Goodwin and Holt (2002). Note that agricultural labor supply in the form of work as an employee of a private farm or cooperative is included in the category of off-farm labor supply. As a result, our treatment of households with access to land as being a self-employed in farming (or a member of a cooperative) is similar to that of Rizov and Swinnen (2004).

${ }^{16}$ Eighteen is the age of graduation from compulsory secondary education in Bulgaria and hence few, if any individuals are involved in formal employment prior to this age. Prior to 1999, 55 was the official retirement age for women and 60 for men in Bulgaria. After 1999, to address the population aging problem, the government initiated a gradual process of increasing the retirement age, indeed by half a year every two years. Since our most recent sample is for 2001, this policy should have no influence on our results.
} 
difference with respect to non-Bulgarian ethnicity increases over time, possibly reflecting increasing discrimination against minorities as unemployment rates rose. Note also that female headed households were increasingly likely to have someone working off-farm.

\section{Regression Results}

Table 2 reports the marginal effects for the probit model that captures the impacts of characteristics of a farm household, both those with respect to farm characteristics (as emphasized in the traditional literature) and the educational, location, ethnicity and other characteristics that would influence access to the limited demand for off-farm labor by at least one of its working age members. The significance of the LR chi-square statistic, as well as psuedo R-square values reported at the bottom of the table indicate that our specification provides a reasonably good fit to the data in all three survey years.

The regression results indicate the following: First, in all three years of the analysis, farm characteristics played a negligible role in determining the likelihood of off-farm labor supply. By contrast, the educational characteristics of household members played an important role in determining the likelihood of off-farm employment in all three years. However, in keeping with our expectations, the most striking finding is that the effects of the different types of education changed substantially over time with the rise in unemployment and the changing skills needed due to privatization and restructuring from industry to services. In 1995, before these radical structural changes, all types of education and especially general secondary education had a positive effect on the likelihood of off-farm employment; but with university education not particularly important. After that, however, while the effects of vocational and higher education became stronger, those of secondary education totally disappeared. Further, consistent with our hypotheses, the impact of university education on the likelihood of off-farm employment was highest in 1997, i.e., in the aftermath of the crisis and the structural reforms.

Second, some of the other variables designed to capture the demand side influences in the labor market also had significant effects on off-farm employment, though generally not as strongly as the educational characteristics of the farm household members. Notably, once again there were interesting variations in these effects over time. In 1995, the only non-educational demand side factor that played a role in determining this likelihood was location; households in or close to urban locations being more likely to find off-farm employment. In the crisis year 1997, on the other hand, the key non-educational factor driving this likelihood was a farm household's non-wage (or asset) income, reflecting its connections to commercial activities and its ability to bear search costs in a market characterised by widespread unemployment, in the wake of industrial restructuring. By 2001, however, still with high unemployment rates but off-farm employment dominated by the private sector, prima facie evidence of discrimination against minorities was apparent. In 2001, even after controlling for education, location and demographic characteristics of the households, ethnic minority 
(or non-Bulgarian) households had become less likely to gain access to off-farm jobs than households of Bulgarian ethnicity.

Finally, a few other household level characteristics are also shown to have affected the likelihood of off-farm employment. Of these, the most notable are the proportion of elderly people in the household, the mean of adults in the household, and the gender of the household head. The likelihood of off-farm employment was negatively related to both the proportion of elderly people and the dummy for a female headed household, suggesting that older workers and members of poorer households may have been less employable in off-farm activities. The lower employability of members of poorer households is consistent with the major body of development theory (e.g., Dasgupta, 1993) and also with the importance of the ability to bear search costs in determining labor market outcomes. The negative impact of the proportion of elderly people in the household might imply the need for these and/or other potential workers in the household to remain at home to provide care. However, the fact that no such negative influence is observed for the proportions of children in the household (and that the effect of the proportion of those 0-6 is positive and significant in the crisis year 1997) casts doubt on the need to provide care at home explanation and possibly points to the greater need for outside employment in the presence of young children with needs that the farm cannot supply. Moreover, the declining relevance of the skills and experience of older workers is also supported by the strong negative effect of the square of mean age of adults.

As such, our results are consistent with our hypothesis that the farm-owning households in our sample are involved in subsistence farming such that off-farm labor supply by these households is driven by demand for labor in the off-farm labor market. It is possible, however, that the sample may consist largely of subsistence farmers, it could also include a fair number of genuine commercial farmers with behavior resembling that of farm households in the neo-classical literature in which the separation principle is deemed to hold. ${ }^{17}$

In order to examine this possibility, we distinguish between commercial and non-commercial farms in our sample, on the basis of data on sale of agricultural produce. In the absence of any obvious cut-off sale volume for a subsistence farmer, we opt for the conservative cut off of zero sales; a household is deemed to a subsistence farmer if it does not sell any of its production, and a commercial farmer if it sells any of it.. Even with this restrictive criterion, we find that in our samples for 1995, 1997 and 2001, the proportions of subsistence or non-commercial farms are 79 percent, 71 percent and 85 percent, respectively. We estimate our model separately for both subsistence and commercial farms, for each of the years, and find that the results are remarkably similar for both types of farms, with off-farm labor supply being determined not by farm characteristics but by education of

\footnotetext{
${ }^{17}$ We thank an anonymous referee for drawing our attention to this possibility.
} 
household members and other factors such as (urban) location that affect labor demand. ${ }^{18}$ In the interest of brevity, we do not report these results, but they are available upon request.

\section{Conclusions}

Three general conclusions emerge from this study.

First, and foremost, our results for Bulgaria confirm that in the context of transition or, more generally, in circumstances where on-farm labor and land productivity were very low and off-farm labor markets are subject to adverse shocks as in privatization, financial or other crises, observed offfarm employment is almost completely explained by the particular characteristics that would make members of farm households especially attractive to off-farm employers. Hence, whereas in more normal years, education of each higher level of education is likely to boost employability, in a crisis year only the highest level (university education) is shown to help much and the benefit of general secondary education is negligible. Similarly, asset or non-labor income, instead of having a negative effect on off-farm labor supply as in the standard supply- driven models of labor supply, has a strong and highly significant positive in the crisis year 1997. Similarly, the negative effect of female headship is large and significant only in the crisis year 1997 and in 2001 when unemployment was still just as high. By the same token, the negative effect of the ethnic minority dummy is negative and significant only when both unemployment is high and privatization had progressed quite far. While in normal years, there is an extremely strong negative effect of the proportion of household members over 60 and the positive effect of the mean age of adults is relatively low, the former is less negative and less significant and the latter more positive and more significant in the crisis year 1997. The asset income, female headship, ethnic minority and age effects would seem to suggest that households with asset income, male heads, non-minority status and somewhat older adults, may all be better connected to job providers and better able to finance job search than others. This conclusion should be of importance for planning programs designed to target the kinds of farm households which would be most adversely affected by financial or other crises in the non-farm sector. It also underscores the importance of farm households accumulating assets and developing contacts with potential off-farm employers during good years to help them in job search and securing off-farm employment in crisis years. Finally, it calls attention to the greater vulnerability of ethnic minorities to discrimination in off-farm labor markets when state firms are privatized.

Second, since all three of the surveyed years were characterized by excess supply in off-farm labor markets, as hypothesized, there is virtually no evidence of the influence of farm characteristics or substitutions among activities within farm households that are suggested in the standard

\footnotetext{
18 There was no convergence for the "commercial" sample for 2001 which was comprised of only 77 observations. However, the very fact that 85 percent of the households in the sample were non-commercial or subsistence even on the basis of a very restrictive criterion suggests that our treatment of these households as subsistence farmers was generally valid for 2001 as well.
} 
neoclassical models of off-farm labor supply. Similarly, there is little support for the argument that off-farm employment is an ex post consumption-smoothing reaction to low farm income.

Third, while education continued to play perhaps the most important role throughout the Bulgarian transition, as unemployment increased and restructuring brought new skills to the fore and rendered some old ones redundant, the usefulness of different types and levels of education changed rather sharply. In particular, the importance of vocational and university education increased while the earlier positive effect of general secondary education declined and by 2001 disappeared altogether. Given the likelihood that periodic shocks from financial crises and adverse trade shocks in this increasingly globalized world will continue to be felt from time to time and that many countries have not yet experienced the restructuring that comes with privatization and opening up to the outside world, it is believed that the lessons of experience with the dramatic shocks in the off-farm sector in the transition economies of CEE and elsewhere will continue to be valuable for the indefinite future.

Naturally, it would be highly desirable to extend this research in the following directions: (1) by examining the consequences for the influences noted here after environmental conditions in Bulgaria changed for the better after 2001 and agricultural productivity may have increased somewhat; (2) to compare the off-farm labor experience in other transition economies and developing countries going through restructuring and the crises they breed to see how general the patterns observed in Bulgaria were, and (3) to examine the influence of other farm characteristics and off-farm employment characteristics not measured in the BIHS surveys utilized in this study. 


\section{References}

Aberg, Rune (2003). Unemployment persistency, over-education and the employment chances of the less educated. European Sociological Review, 19(2): 199-216.

Abrams, Burton A.and Plamen K.Yossifov (2003). The importance of property rights for economic outcomes: Lessons from the transfer of productive assets from collective to private ownership in Bulgarian agriculture. Proceedings of Enterprise in Transition ( $5^{\text {th }}$ international conference), 49-51.

Alderman, Harold and Christina H. Paxson (1992). Do the poor insure? A synthesis of the literature on risk and consumption in developing countries. The World Bank, Washington, D.C.: Policy Research Working Paper 1008.

Bachev, Hrabin (2008). Production and productivity of Bulgarian agriculture in post war years. Munich: Munich Personal RePEc Archive Paper No 7787.

Barrett, Christopher B., Mesfin Bezuneh, Daniel C. Clay and Thomas Reardon (2000). Heterogeneous constraints, incentives and income diversification strategies in rural Africa. Mimeo, Cornell University, http://ssrn.com/abstract=258371.

Barrett, Christopher B., Thomas Reardon and Patrick Webb (2001) Nonfarm income diversification and household livelihood strategies in rural Africa: Concepts, dynamics and policy implications, Food Policy, 26(4), 315-331.

Benjamin, Dwayne (1992) Household composition, labor markets and labor demand: Testing for separation in agricultural household models. Econometrica, 60, 287-322.

Bezemer, Dirk J. (2004). Risk and agricultural de-collectivisation, with evidence from the Czech Republic, Economic Systems, 28 (1), 13-33.

Blanchard, Olivier, Simon Commander and Fabrizio Coricelli (1995). Unemployment and restructuring in Eastern Europe and Russia, In: Simon Commander and Fabrizio Coricelli (Eds.) Unemployment, Restructuring, and the Labor Market in Eastern Europe and Russia, Washington, D.C.: Economic Development Institute, The World Bank.

Bolton, Patrick, Gerard Rolond, John Vickers and Michael Burda (1992). Privatization policies in Central and Eastern Europe, Economic Policy, 7 (15), 275-309.

Burda, Michael, Charles Bean and Jan Svejnar (1993). Unemployment, labour markets and structural changes in Eastern Europe, Economic Policy, 8 (16), 101-137.

Dasgupta, Partha and Debraj Ray (1986). Inequality as a determinant of malnutrition and unemployment, I, Theory. Economic Journal, 96, 1011-1034.

Dasgupta, Partha (1993). An inquiry into well-being and destitution. Oxford: Oxford University Press.

De Janvry, Alain and Elisabeth Sadoulet (2001). Income strategies among rural households in Mexico: The role of off-farm activities. World Development, 29 (3), 467-480.

Deininger, Klaus and Pedro Olinto (2001). Rural nonfarm employment and income diversification in Columbia. World Development, 29 (3), 455-465.

Dessing, Maryke (2002). Labor supply, the family and poverty: The S-shaped labor supply curve. Journal of Economic Behavior and Organization, 49, 433-458. 
Dimova, Ralitza and Ira Gang (2004). Self selection and earnings during volatile transition. IZA, Bonn: Working paper no. 1158.

Dimova, Ralitza (2006). "Monopolistic wages or efficient contracts?. What determined the wageemployment bargain in post-privatization Bulgaria?” Economics of Transition, 14(2), 321-348.

Dobbelaere, Sabian (2004). Ownership, firm size and rent sharing in Bulgaria. Labor Economics 11 (2), 165-189.

Dobrinsky, Rumen (2000). The transition crisis in Bulgaria. Cambridge Journal of Economics, 24, 581-502.

Escobal, Javier (2001). The determinants of nonfarm income diversification in Peru. World Development, 29 (3), 497-508.

Faggio, Giulia and Jozef Konings (2003). Job creation, job destruction and employment growth in transition countries in the 90s, Economic Systems, 27 (2), 129-154.

Falaris, Evangelos M. (2004). Private and public wages in Bulgaria. Journal of Comparative Economics, 32 (1), 56-72.

Goodwin, Barry K. And Matthew T. Holt (2002). Parametric and semiparametric 15odelling of the off-farm labor supply of agrarian households in transition Bulgaria. American Journal of Agricultural Economics, 84, 184-209.

Heckman, James (1979). Sample selection bias as specification error. Econometrica, 47, 153-161.

Huffman, Wallace E. (1980). Farm and off-farm work decisions: The role of human capital. Review of Economics and Statistics, 62 (1), 14-23.

Huffman, Wallace E. And Mark D. Lange (1989). Off-farm work decisions of husbands and wives: Joint decision making. Review of Economics and Statistics, 71 (3), 471-480.

Jacoby, Hanan G. (1993). Shadow wages and peasant family labor supply: An econometric application to the Peruvian Sierra. Review of Economic Studies, 60 (4), 903-921.

Jolliffe, Dean (2004). The impact of education in rural Ghana: Examining household labor allocation and returns on and off the farm. Journal of Development Economics, 73, 287-314.

Kimhi. Ayal (2004). Family consumption and off-farm participation decisions in Israeli farm households. American Journal of Agricultural Economics, 86 (2), 502-512.

Koford, Kenneth and Jeffrey B. Miller (2006). Contract enforcement in the early transition of an unstable economy, Economic Systems, 30 (1), 1-23.

Konings, Jozef, Hartmut Lehman and Mark E. Schaffer (1996). Job creation and job destruction in a transition economy: Ownership, firm size, and gross job flows in Polish manufacturing 1988-91, Labour Economics, 3, 299-317.

Kopeva, Diana and Nivelin Noev (2001). Aspects of land consolidation after the land reform in Bulgaria. In Ieda Osamu (Ed.), The New Structure of the Rural Economy of Post-communist Countries, Slavic Research Center, Hokkaido University, Sapporo, Japan, 2001, pp.123-159.

Lamb, Russell L. (2003). Fertilizer use, risk and off-farm labor markets in the semi-arid tropics of India. American Journal of Agricultural Economics, 85 (2), 359-371. 
Lanjouw, Jeane O. And Peter Lanjouw (1995). Rural non-farm employment: A survey, Washington, D.C.: World Bank, Policy Research Working paper 1463.

Lewis, Arthur (1954). Economic development with unlimited supplies of labor. Manchester School, $22(2), 131-191$.

Mickiewicz, Tomasz, Christopher J. Gerry and Kate Bishop (2005). Privatisation, corporate control and employment growth: Evidence from a panel of large Polish firms, 1996-2002, Economic Systems, 29 (1), 98-119.

Mishra, Ashok K. And Barry K. Goodwin (1998). Income risk and allocation of labor time: An empirical investigation. Applied Economics, 30, 1549-1555.

Nelson, Forrest D. (1977) Censored regression models with unobserved, stochastic censoring thresholds. Journal of Econometrics, 6, 309-327.

Noev, Nevelin, Swinnen, Johann and Liesbet Vranken (2004). Fragmentation, abandonment and coownership: Transition problems of the Bulgarian market. Quarterly Journal of International Agriculture, 43, 391-408.

Oldenhanna, T. and A. Oskan (2001). Income diversification and entry barriers: Evidence from the Tigray region of Northern Ethiopia. Food Policy, 26, 351-365.

Pauna, Catalin and Bianca Pauna (1999). Output decline labor reallocation in transitional economics: Where does Romania stand? In Christof and Daniel Daiamu (Eds.) Economic Transition in Romania. Proceedings of the Conference "Romania 2000: 10 Years of Transition - Past, Present and Future".

Reardon, Thomas, C. Delgado and P. Matlon (1992). Determinants and effects of income diversification amongst farm households in Burkina Faso, Journal of Development Studies, 28 (2), 264-296.

Reardon, Thomas (1997). Using evidence of household income diversification to inform study of the rural nonfarm labor market in Africa. World Development, 25 (5), 735-747.

Reardon, T., K. Stamoulis, A. Balisacan, ME Cruz, J. Berdegue, B. Banks. (1998). Rural nonfarm income in developing countries. The State of Food and Agriculture 1998, Rome: Food and Agricultural Organization of the United Nations.

Rizov, Marian and Johan F. M. Swinen (2004). Human capital, market imperfections, and labor reallocation in transition, Journal of Comparative Economics, 32, 745-774.

Rosenzweig, Mark R. (1980). Neoclassical theory and the optimizing peasant: An econometric analysis of market family labor supply in a developing country. Quarterly Journal of Economics, 94 (1), 31-55.

Rozelle, Scott D. and Johan F.M. Swinnen (2004). Success and failure of reform: Insights from the transition and agriculture, Journal of Economic Literature, 42 (2), 404-456.

Rutkowski, Jan (1999). Labor markets and poverty in Bulgaria. The World Bank, Washington, D.C.: Social protection discussion paper no. 9918.

Sahn, David E., Stephen D. Younger and Chad Meyerhoefer (2002). Rural poverty in Bulgaria: Characteristics and trends. Mimeo, College of Human Ecology, Cornell University, Ithaca. 
Schnytzer, Adi and Tatiana Andreyeva (2002). Company performance in Ukraine: Is this a market economy? Economic Systems, 26 (2), 83-98.

Sumner, Daniel A. (1982). The off-farm labor supply of farmers. American Journal of Agricultural Economics, August, 499-509.

Svejnar, Jan (1996). Enterprises and workers in the transition: Econometric evidence, Papers and Proceedings of the Hundred and Eighth Annual Meeting of the American Economic Association, 86 (2), 123-127.

Svejnar, Jan (1999). Labor markets in the transitional Central and East European Economies, In: Orley C. Ashenfelter and David Card (Eds.), Handbook of Labor Economics, Volume 3, No. 2, Elsevier, pp. 2809-2857.

Van den Berg, Marrit and Ruerd Ruben (2001). Nonfarm employment and poverty alleviation of rural farm households in Hunduras. World Development, 29 (3), 549-560.

Walsh, Patrick P. and Ciara Whelen (2001). Firm performance and the political economy of corporate governance: survey evidence for Bulgaria, Hungary, Slovakia and Slovenia, Economic Systems, 25 (2), 85-112.

Weersink, Alfons, Charles Nicholson and Jeeveka Weerhewa (1998). Multiple job holdings among dairy farm families in New York and Ontario. Agricultural Economics, 18, 127-143.

Woldenhanna, T. And A. Oskam (2001). Income diversification and entry barriers: Evidence from the Tigray region of northern Ethiopia. Food Policy, 26, 351-365.

World Bank (2001). Bulgaria: The dual challenge of transition and accession. Country study of the Poverty Reduction and Economic Management Unit for Europe and Central Asia Region. 
Table 1: Means and standard deviations for all variables used in each survey year

\begin{tabular}{|c|c|c|c|c|c|c|}
\hline & \multicolumn{2}{|c|}{1995} & \multicolumn{2}{|c|}{1997} & \multicolumn{2}{|c|}{2001} \\
\hline & $\begin{array}{c}\text { No off- } \\
\text { farm labor }\end{array}$ & $\begin{array}{c}\text { Off-farm } \\
\text { labor }\end{array}$ & $\begin{array}{c}\text { No off- } \\
\text { farm labor }\end{array}$ & $\begin{array}{c}\text { Off-farm } \\
\text { labor }\end{array}$ & $\begin{array}{c}\text { No off- } \\
\text { farm labor }\end{array}$ & $\begin{array}{c}\text { Off-farm } \\
\text { labor }\end{array}$ \\
\hline \multicolumn{7}{|l|}{ Farm characteristics } \\
\hline $\begin{array}{l}\text { Dummy for cooperative } \\
\text { membership }\end{array}$ & $\begin{array}{r}0.09 \\
(0.27)\end{array}$ & $\begin{array}{r}0.06 \\
(0.22)\end{array}$ & $\begin{array}{r}0.20 \\
(0.37)\end{array}$ & $\begin{array}{r}0.15 \\
(0.32)\end{array}$ & $\begin{array}{r}0.03 \\
(0.15)\end{array}$ & $\begin{array}{r}0.04 \\
(0.19)\end{array}$ \\
\hline $\begin{array}{l}\text { Proportion of households reporting } \\
\text { farm equipment }\end{array}$ & $\begin{array}{r}0.39 \\
(0.49) \\
\end{array}$ & $\begin{array}{r}0.39 \\
(0.48) \\
\end{array}$ & $\begin{array}{r}0.26 \\
(0.44) \\
\end{array}$ & $\begin{array}{r}0.33 \\
(0.47) \\
\end{array}$ & $\begin{array}{r}0.33 \\
(0.47) \\
\end{array}$ & $\begin{array}{r}0.33 \\
(0.47) \\
\end{array}$ \\
\hline Size of land (decares) & $\begin{array}{r}41.40 \\
(472.66)\end{array}$ & $\begin{array}{r}8.56 \\
(42.68)\end{array}$ & $\begin{array}{r}25.98 \\
(74.20)\end{array}$ & $\begin{array}{r}36.26 \\
(145.03)\end{array}$ & $\begin{array}{r}77.52 \\
(1454.10)\end{array}$ & $\begin{array}{r}17.30 \\
(79.13)\end{array}$ \\
\hline \multicolumn{7}{|l|}{ Education } \\
\hline $\begin{array}{l}\text { Proportion of adults with general } \\
\text { secondary education }\end{array}$ & $\begin{array}{r}0.14 \\
(0.31)\end{array}$ & $\begin{array}{r}0.21 \\
(0.30)\end{array}$ & $\begin{array}{r}0.19 \\
(0.33)\end{array}$ & $\begin{array}{r}0.20 \\
(0.30)\end{array}$ & $\begin{array}{r}0.16 \\
(0.31)\end{array}$ & $\begin{array}{r}0.15 \\
(0.27)\end{array}$ \\
\hline $\begin{array}{l}\text { Proportion of adults with } \\
\text { vocational education }\end{array}$ & $\begin{array}{r}0.21 \\
(0.37)\end{array}$ & $\begin{array}{r}0.37 \\
(0.38)\end{array}$ & $\begin{array}{r}0.25 \\
(0.42)\end{array}$ & $\begin{array}{r}0.41 \\
(0.37)\end{array}$ & $\begin{array}{r}0.29 \\
(0.42)\end{array}$ & $\begin{array}{r}0.51 \\
(0.40)\end{array}$ \\
\hline $\begin{array}{l}\text { Proportion of adults with } \\
\text { university education }\end{array}$ & $\begin{array}{r}0.04 \\
(0.17) \\
\end{array}$ & $\begin{array}{r}0.09 \\
(0.24) \\
\end{array}$ & $\begin{array}{r}0.04 \\
(0.16) \\
\end{array}$ & $\begin{array}{r}0.12 \\
(0.26) \\
\end{array}$ & $\begin{array}{r}0.03 \\
(0.14) \\
\end{array}$ & $\begin{array}{r}0.08 \\
(0.21) \\
\end{array}$ \\
\hline \multicolumn{7}{|l|}{ Other factors affecting labor demand } \\
\hline Asset/non-labor income & $\begin{array}{r}0.28 \\
(0.45) \\
\end{array}$ & $\begin{array}{r}0.32 \\
(0.47) \\
\end{array}$ & $\begin{array}{r}0.20 \\
(0.40) \\
\end{array}$ & $\begin{array}{r}0.30 \\
(0.46) \\
\end{array}$ & $\begin{array}{r}0.33 \\
(0.47) \\
\end{array}$ & $\begin{array}{r}0.41 \\
(0.49) \\
\end{array}$ \\
\hline Dummy for ethnic minority & $\begin{array}{r}0.21 \\
(0.41) \\
\end{array}$ & $\begin{array}{r}0.13 \\
(0.34) \\
\end{array}$ & $\begin{array}{r}0.20 \\
(0.40) \\
\end{array}$ & $\begin{array}{r}0.15 \\
(0.36) \\
\end{array}$ & $\begin{array}{r}0.31 \\
(0.46) \\
\end{array}$ & $\begin{array}{r}0.12 \\
(0.32) \\
\end{array}$ \\
\hline Dummy for urban location & $\begin{array}{r}0.25 \\
(0.43) \\
\end{array}$ & $\begin{array}{r}0.51 \\
(0.50)\end{array}$ & $\begin{array}{r}0.38 \\
(0.49) \\
\end{array}$ & $\begin{array}{r}0.54 \\
(0.50) \\
\end{array}$ & $\begin{array}{r}0.24 \\
(0.43) \\
\end{array}$ & $\begin{array}{r}0.44 \\
(0.50) \\
\end{array}$ \\
\hline \multicolumn{7}{|c|}{ Control variables: Other household characteristics } \\
\hline Number of adults & $\begin{array}{r}1.88 \\
(0.98)\end{array}$ & $\begin{array}{r}2.62 \\
(1.05)\end{array}$ & $\begin{array}{r}2.03 \\
(1.09)\end{array}$ & $\begin{array}{r}2.61 \\
(1.01)\end{array}$ & $\begin{array}{r}1.92 \\
(1.03)\end{array}$ & $\begin{array}{r}2.63 \\
(1.11)\end{array}$ \\
\hline Mean age of adults & $\begin{array}{l}46.49 \\
(9.90) \\
\end{array}$ & $\begin{array}{l}39.90 \\
(7.45) \\
\end{array}$ & $\begin{array}{r}43.96 \\
(10.02) \\
\end{array}$ & $\begin{array}{r}39.88 \\
(7.06) \\
\end{array}$ & $\begin{array}{r}44.41 \\
(10.30)\end{array}$ & $\begin{array}{l}40.89 \\
(7.84) \\
\end{array}$ \\
\hline Mean age if adults sq. & $\begin{array}{r}0.05 \\
(0.16) \\
\end{array}$ & $\begin{array}{r}0.11 \\
(0.23) \\
\end{array}$ & $\begin{array}{r}0.06 \\
(0.18) \\
\end{array}$ & $\begin{array}{r}0.09 \\
(0.20) \\
\end{array}$ & $\begin{array}{r}0.07 \\
(0.20) \\
\end{array}$ & $\begin{array}{r}0.08 \\
(0.17) \\
\end{array}$ \\
\hline $\begin{array}{l}\text { Proportion of household members } \\
0-6\end{array}$ & $\begin{array}{r}0.19 \\
(0.39) \\
\end{array}$ & $\begin{array}{r}0.31 \\
(0.42)\end{array}$ & $\begin{array}{r}0.24 \\
(0.47)\end{array}$ & $\begin{array}{r}0.28 \\
(0.39) \\
\end{array}$ & $\begin{array}{r}0.26 \\
(0.44) \\
\end{array}$ & $\begin{array}{r}0.27 \\
(0.41) \\
\end{array}$ \\
\hline $\begin{array}{l}\text { Proportion of household members } \\
7-18\end{array}$ & $\begin{array}{r}0.5921 \\
(0.6588) \\
\end{array}$ & $\begin{array}{r}0.2701 \\
(0.4507) \\
\end{array}$ & $\begin{array}{r}0.5333 \\
(0.6511) \\
\end{array}$ & $\begin{array}{r}0.2883 \\
(0.5032) \\
\end{array}$ & $\begin{array}{r}0.5267 \\
(0.6473) \\
\end{array}$ & $\begin{array}{r}0.3232 \\
(0.5152) \\
\end{array}$ \\
\hline $\begin{array}{l}\text { Proportion of household members } \\
\text { older than } 60\end{array}$ & $\begin{array}{r}0.2561 \\
(0.2511)\end{array}$ & $\begin{array}{r}0.1195 \\
(0.1763)\end{array}$ & $\begin{array}{r}0.2254 \\
(0.2354)\end{array}$ & $\begin{array}{r}0.1276 \\
(0.1610)\end{array}$ & $\begin{array}{r}0.2265 \\
(0.2496)\end{array}$ & $\begin{array}{r}0.1427 \\
(0.1948) \\
\end{array}$ \\
\hline Dummy for female head & $\begin{array}{r}0.77 \\
(0.42) \\
\end{array}$ & $\begin{array}{r}0.86 \\
(0.35) \\
\end{array}$ & $\begin{array}{r}0.51 \\
(0.50) \\
\end{array}$ & $\begin{array}{r}0.70 \\
(0.46) \\
\end{array}$ & $\begin{array}{r}0.52 \\
(0.50) \\
\end{array}$ & $\begin{array}{r}0.70 \\
(0.46) \\
\end{array}$ \\
\hline Number of observations & 189 & 397 & 241 & 389 & 209 & 336 \\
\hline
\end{tabular}

Note: The values within parentheses are standard deviations. The unit of measurement is households. 
Table 2: Determinants of off-farm labor supply (Probit analysis - marginal effects)

\begin{tabular}{|c|c|c|c|}
\hline & 1995 & 1997 & 2001 \\
\hline \multicolumn{4}{|l|}{ Farm characteristics } \\
\hline Dummy for cooperative membership & $\begin{array}{c}-0.04 \\
(0.08)\end{array}$ & $\begin{array}{c}-0.06 \\
(0.05)\end{array}$ & $\begin{array}{l}0.04 \\
(0.11)\end{array}$ \\
\hline Dummy for farm equipment & $\begin{array}{l}0.05 \\
(0.04)\end{array}$ & $\begin{array}{l}0.06 \\
(0.04)\end{array}$ & $\begin{array}{l}0.02 \\
(0.05)\end{array}$ \\
\hline Size of land (decares) & $\begin{array}{c}-0.0004 \\
(0.0001)\end{array}$ & $\begin{array}{r}-0.00004 \\
(0.0002)\end{array}$ & $\begin{array}{r}-0.00005 \\
(0.00004)\end{array}$ \\
\hline \multicolumn{4}{|l|}{ Education } \\
\hline Proportion of adults with general secondary education & $\begin{array}{l}0.19 * * * \\
(0.07)\end{array}$ & $\begin{array}{l}0.10 \\
(0.07)\end{array}$ & $\begin{array}{l}0.002 \\
(0.08)\end{array}$ \\
\hline Proportion of adults with vocational education & $\begin{array}{l}0.15 * * \\
(0.06)\end{array}$ & $\begin{array}{l}0.21 * * * \\
(0.06)\end{array}$ & $\begin{array}{l}0.27 * * * \\
(0.06)\end{array}$ \\
\hline Proportion of adults with university education & $\begin{array}{l}0.18 * \\
(0.11)\end{array}$ & $\begin{array}{l}0.48 * * * \\
(0.11)\end{array}$ & $\begin{array}{l}0.39 * * * \\
(0.014)\end{array}$ \\
\hline \multicolumn{4}{|l|}{ Other factors affecting labor demand } \\
\hline Asset/non-labor income & $\begin{array}{l}0.07 \\
(0.04)\end{array}$ & $\begin{array}{l}0.14 * * * \\
(0.04)\end{array}$ & $\begin{array}{l}0.08 \\
(0.05)\end{array}$ \\
\hline Dummy for ethnic minority & $\begin{array}{r}-0.10 \\
(0.04)\end{array}$ & $\begin{array}{l}0.07 \\
(0.04) \\
\end{array}$ & $\begin{array}{c}-0.39 * * * \\
(0.07)\end{array}$ \\
\hline Dummy for urban location & $\begin{array}{l}0.14 * * * \\
(0.04)\end{array}$ & $\begin{array}{c}-0.07 \\
(0.07)\end{array}$ & $\begin{array}{l}0.04 \\
(0.05)\end{array}$ \\
\hline Regional dummy variables & Yes & Yes $* * *$ & Yes \\
\hline \multicolumn{4}{|l|}{ Control variables } \\
\hline Number of adults & $\begin{array}{l}0.05 * \\
(0.03)\end{array}$ & $\begin{array}{l}0.01 \\
(0.03)\end{array}$ & $\begin{array}{l}0.10 * * * \\
(0.02)\end{array}$ \\
\hline Mean age of adults & $\begin{array}{l}0.06 * * * \\
(0.02)\end{array}$ & $\begin{array}{l}0.11 * * * \\
(0.02)\end{array}$ & $\begin{array}{l}0.05 * * \\
(0.02)\end{array}$ \\
\hline Mean age if adults sq. & $\begin{array}{c}-0.0008 * * * \\
(0.0002)\end{array}$ & $\begin{array}{c}-0.001 * * * \\
(0.0002)\end{array}$ & $\begin{array}{c}-0.0007 * * \\
(0.0003)\end{array}$ \\
\hline Proportion of household members 0-6 & $\begin{array}{l}0.23 \\
(0.23)\end{array}$ & $\begin{array}{l}0.53 * * \\
(0.25)\end{array}$ & $\begin{array}{l}0.04 \\
(0.29)\end{array}$ \\
\hline Proportion of household members 7-18 & $\begin{array}{l}0.05 \\
(0.14)\end{array}$ & $\begin{array}{c}-0.02 \\
(0.15)\end{array}$ & $\begin{array}{l}0.02 \\
(0.15)\end{array}$ \\
\hline Proportion of household members older than 60 & $\begin{array}{c}-0.33 * * * \\
(0.12)\end{array}$ & $\begin{array}{c}-0.27 * \\
(0.14)\end{array}$ & $\begin{array}{c}-0.31 * * \\
(0.14)\end{array}$ \\
\hline Dummy for female head & $\begin{array}{l}0.08 \\
(0.07)\end{array}$ & $\begin{array}{c}-0.19 * * \\
(0.08)\end{array}$ & $\begin{array}{l}-0.23 * * * \\
(0.07)\end{array}$ \\
\hline Dummy for married head & $\begin{array}{l}0.11 \\
(0.07)\end{array}$ & $\begin{array}{l}0.03 \\
(0.06) \\
\end{array}$ & $\begin{array}{l}0.04 \\
(0.06)\end{array}$ \\
\hline Log likelihood & -276.76 & -330.09 & -265.37 \\
\hline LR chi-square & $183.37 * * *$ & $178.08 * * *$ & $194.91 * * *$ \\
\hline Pseudo R-square & 0.25 & 0.21 & 0.27 \\
\hline Number of observations & 586 & 630 & 545 \\
\hline
\end{tabular}

Notes: The values with parentheses are robust standard errors. ***, ** and * indicate significance at $1 \%, 5 \%$ and $10 \%$ levels, respectively. The unit of measurement is households. 